\title{
History of Economic Thought as an Analytic Tool: why Past Intellectual Ideas Must Be Acknowledged as Lighthouses for the Future
}

\author{
Dieter Bögenhold ${ }^{1}$ (iD
}

Published online: 14 March 2020

(C) The Author(s) 2020

\begin{abstract}
Contemporaries tend to question certain belief systems including academic systems of knowledge. Paradigms evolve to become a subject of inquiry. The need to acknowledge history of economic thought as a neglected but important domain of economic inquiry as an important discussion topic. During recent decades, history of economic thought has largely been abolished and has disappeared from many contemporary teaching curricula in economics. The article argues that our academic understanding of economics is incomplete if we do not respect history and understand the social embeddedness of economic institutions and social behaviour. Of course, one must distinguish between history of intellectual ideas and economic history. Both items have to be discussed separately when assessing methodological appropriateness and benefits. The argumentation is based on the work of Joseph A. Schumpeter who dealt in detail with the question why and how to deal with historiography as a tool of proper economics in his substantial introduction to the 1945 book History of Economic Analysis.
\end{abstract}

Keywords History of economic thought · Methodology

JEL $\mathrm{B} 15 \cdot \mathrm{B} 25 \cdot \mathrm{B} 30 \cdot \mathrm{B} 52$

\section{Economics within Social Sciences: Specialization and Differentiation}

Economic theory as a body of common knowledge is never stationary nor a stable set of monolithic systems of academic belief but it is always embedded in changes of

Dieter Bögenhold

Dieter.boegenhold@aau.at

1 Faculty of Economics and Management, Alpen-Adria University Klagenfurt, Universitätsstrasse 65-67, 9020 Klagenfurt, Austria 
intellectual thought and related processes of struggle. What the ancient Greek philosopher Heraklitus meant by "everything flows", is also valid for social sciences. John Maynard Keynes came up with his observation very clearly:

"The ideas of economists and political philosophers, both when they are right and when they are wrong, are more powerful than is commonly understood. Indeed, the world is ruled by little else. Practical men, who believe themselves to be quite exempt from any intellectual influences, are usually the slaves of some defunct economist" (Keynes 1936, p. 383).

When an economic crisis occurs, as was the case in 2008, contemporaries tend to question certainties of belief systems including academic systems of knowledge. Existing paradigms evolve to become a subject of inquiry. Among those new topics is a claim to acknowledge the history of economic thought (HET) as an important, although neglected, domain of economic inquiry. During the last decades, HET has mostly been abolished or has disappeared in many contemporary teaching curricula in economics. When the latest methods in econometrics and mathematical procedures are put into the reading schedule in university education, reading of the history of our own discipline appears to be nearly forgotten. In general, the study of the history of economic thought is held in low esteem by "mainstream economists and sometimes openly disparaged as a type of antiquarianism" (Blaug 2001, p. 145). An unforecasted crisis, such as the economic crisis and downturn in 2008, teaches us that our academic understanding of economic processes may be incomplete, that our analysis of economic relationships must be more comprehensive, integrating further perspectives of thought, and that contemporaries cannot afford to have a good command of economics without a working knowledge of the changes in and the tradition of our own subject.

Although there exist active professional societies in many countries which try to celebrate and foster the history of economic thought, especially the U.S.-based History of Economics Society (HES) and the European Society for the History of Economic Thought (ESHET), which each have an annual conference, maintain journals and many further activities, it does not look as if those societies and related scholars belong to the core faculties of the subject economics. Practice tells us that courses in history of economics are taught less and less, and in many institutions, they are no longer part of the curriculum (Roncaglia 2014). Many even raise the question of whether the history of economics should be considered a subject of history rather than of economics (Kates 2013).

However, can we learn anything by reading in history of economic theory, and, if yes, what may it be? Peter Boettke raised the pertinent question: Why, indeed, read the classics in economics?

"There are antiquarian reasons - reading the works of the great political economists of the past does give us a glimpse of the genius of an earlier age. But reading an old work in economics is not unlike watching a silent film or news clips of an old baseball game. It is quaint and romantic to look in on the past, but it is useful to remember that this world we sometimes worship from afar was a world without indoor plumbing, without modern transportation..." (Boettke 2000, p. 1). 
This paper is about the question why it is not only useful but also necessary to invest into history of economic thought.

It is difficult to clarify the domain of economics in clear words when teaching undergraduates. Usually we operate with simplifications, which highlight a general theory as a body of "cohesive ideas set within a structure that seems internally consistent" (Wunder 2010, p. 23). As Viner put it in 1917: "There is a tendency among economists to fear over much for the integrity of their science and to try to maintain its borders intact by carefully avoiding encroachment on the fields of other science" (Viner 2017, p. 236). At a first glance, such a monolithic view of theory may be convincing, since it does not acknowledge contradictions, empirical failures, a plurality of competing paradigms and, especially, it ignores change.

"Methodology used by economists today is very different from what was used 30 years ago, and what was used 30 years ago was very different from the methodology used by such great economists as Adam Smith and David Ricardo. The economic methodology that is taught in undergraduate courses today is the result of centuries of intellectual debate, and the origin of this body has been filled with differing thinkers often in violent disagreement with each other" (Wunder 2010, p. 23).

Man contemporary academic disciplines, not only economics, are experiencing a flood of material in terms of publications and new people (Bögenhold 2010). The topics have multiplied in many directions and whole new areas of discourse have emerged (Chafim 2016), each with separate research organizations, global conferences, journals, curricula, academic career opportunities, as well as patterns and publication opportunities. Parallel, shifting disciplinary boundaries have been observed inside and outside economics (Cedrini and Fiori 2016). During the second part of the twentieth century, an organizational segmentation began, which provided proof of Max Weber's statement given in his famous article "Science as Vocation" (1988a), namely that the individual can achieve something really substantial on academic ground only in a situation of increased specialization:

"In our time, the internal situation, in contrast to the organization of science as a vocation, is first of all conditioned by the facts that science has entered a phase of specialization previously unknown and that this will forever remain the case. Not only externally, but inwardly, matters stand at a point where the individual can acquire the sure consciousness of achieving something truly perfect in the field of science only incase he is a strict specialist" (Weber 1988a, p. 526).

A variety of new specialized fields of economics were founded, among them industrial economics, labour economics, small business economics, household economics, economics of aging, but most notably game theory and diverse applications in combination with econometrics. Use of advanced statistics and econometrics have expanded substantially, (Weintraub 2002; Morgan 2012) which can be summarized broadly as diverse sorts of "mathiness" (Romer 2015). Taken together, one may conclude that we have entered "The Age of the Applied Economist" (Backhouse and Cherrier 2017) where elegant theoretical reasoning and historical foundation are being lost. Discussing 
"The Future of the History of Economics" (Davis et al. 2002) showed the need to acknowledge the history of economics and other social sciences, but also serious practical weaknesses in doing so in times when the history of economics is out of fashion. This paper will primarily present the perspective of Joseph A. Schumpeter, who dealt in detail with the questions of how to deal with historiography as a tool for appropriate economics in his substantial introduction to the History of Economic Analysis (1954). While points of discussion and neglect of history occurred for many years, it is less known that Schumpeter (1954) already pointed out very clearly that history of thought must be acknowledged because it provides a manual to gain systematic knowledge in order to be better equipped for research on future developments.

\section{Loss of History of Economic Thought}

Recently there has been a tricky situation in economics. On the one hand, there is increased specialization, abstractness and mathiness, and on the other hand, there are ongoing tendencies toward processes of an increased pluralization of economics (Hodgson et al. 1992; Schabas 1992; Davis 2006), but there is obviously no specialization for HET anymore. Economics was applauded for its empiricism in the direction of further social sciences (Lazear 2000; Fourcade et al. 2015) or blamed for having forgotten its social foundations (Buckley and Casson 1993; Granovetter 2002; Davis 2016; Chafim 2016; Marchionatti and Cedrini 2017). Many new areas have evolved and serve as impressive fields of the general trend of academic specialization and differentiation. The more complex economics has become, the smaller the real terrain of neoclassical theory remains; although the general image of economics, especially when looking from the outside, still shows a dominance of neoclassical orthodoxy. However, mainstream economics is also fragmented and always changing (Cedrini and Fontana 2018). The twenty-first century looks back at this scientific period of development, differentiation and consolidation as a feature of the twentieth century.

Economics has changed and the types of economists are changing. The former link, which was maintained by economics and further social science domains, especially philosophy, was exchanged for the link of econometrics and mathematics. Mainstream economics became increasingly associated with abstractness and formalism, which went along with an ongoing trend that the history of economic theory was disregarded. In other words, economics has started to forget history (Hodgson 2001). History of economic theory was abolished or pushed to different disciplines (philosophy or science theory). Hodgson argued that:

"prowess with formal technique has replaced the broader intuitive, methodological and historical intellectual grounding required of the great economist. Such qualities were emphasized and personified by both Alfred Marshall and John Maynard Keynes. Today, economists are no longer systematically educated in economic history, the philosophy of science or the history of their own discipline" (2007, p. 19). 
What Heilbroner wrote in 1979, namely that the history of economic thought is taught on a very small scale, has become even smaller since then.

"The history of economic thought is not in very high esteem these days. Few universities include it as a prescribed portion of the standard training curriculum for budding economists. The history of thought is usually taught in a single semester in which the student dashes through Physiocracy to Smith and Ricardo, stops for a moment to regard from afar the mysterious figure of Karl Marx, learns about the Marginalist Revolution, and is finally delivered safely to the arms of Modern Economics when he reaches the 1930s and the General Theory is born" (Heilbroner 1979, p. 192).

Practically, history of economic thought is regarded as something which is disappearing (Vaughn 1993; Backhouse 1994; Samuels 1997; Fogarty and Naples 1998; Laidler 2001), a fact which was already noted in the early 1960s (Winch 1962), since many contemporaries did not acknowledge history of economic thought as part of the domain of economics (Blaug 2001). What Boulding (1971) reported more than 45 years ago, namely that modern graduates have rarely read a piece which is older than 10 years, is still true (Roncaglia 2014). The half-life knowledge of publications is getting shorter and shorter. ${ }^{1}$ Also the number of publications in history of economics has declined compared to the total of publications in economics while a large body of those publications are concentrated in just five highly specialized journals (Marcuzzo and Zacchia 2016, 36).

The trade-off is that recent graduates of economic studies are more competent in the application of mathematics and statistics and ambitious computer simulations, than in having a working knowledge of the history of a specific subject. In mathematics, the small multiplication table is a precondition for the larger multiplication tables, but in modern economics, one can skip the elementary steps contained within the history of economic ideas. In other words,

"recruitment and professional advancement are almost on the basis of technical competence, rather than on knowledge of the real economy or of the evolution of economics as a discipline. This bias towards formalism has become deeply ingrained and institutionalized in the academy. It is compounded by the fragmentation of the profession into technical specialisms, often lacking the generalist background that enables communication and synthetic advance", Hodgson (2007, p. 19).

\section{History of Economic Thought and Historiography}

History of economic thought is practically historiography. Talk about historiography oscillates between the two quite different perspectives of writing history in practice as

\footnotetext{
1 "The antihistorical school, which is now so common in the United States, where the history of thought is regarded as slightly depraved entertainment, fit only for people who really like medieval Latin, so that one became a fully-fledged, chartered Ph.D. economist without ever reading anything that was published more than ten years ago ..." (Boulding 1971, p. 232-33).
} 
used by social and economic historians and methodological reflections on the use of history as a heuristic tool. The double-sided understanding of historiography as data collecting and synthesizing for economies and societies on the one hand and of a methodological tool to arrive at a deeper understanding of processes inherent to sciences and their change, on the other hand, is not always clearly separated in practice.

The term "historiography," literally "the writing of history," carries two distinct meanings.

"On the one hand, it refers to historical accounts of the past, in contrast to the past itself. On the other hand, the term is used in a meta-theoretical sense as the reflection on how historians account for the past. Historiography in this second sense has two aspects. It may refer either to the particular historical methods employed by the historian, or to a broader reflection on the methodology underlying her historical research. According to the broader interpretation, historiography is to the practice of the history of economics what the methodology of economics is to the practice of economics. An additional complexity arises because both history and methodology of economics are meta-discourses ... in respect to the discipline of economics, which increasingly draw upon one another" (Klaess 2003, p. 491).

Just reading a contemporary piece in economics (or any other social science) does not allow one to get the full sense of that piece, if one does not understand the context of creation. Ideas, it was said, have their own history; telling the story of an idea's development was "internal" or "absolutist" history (Emmet 2003, p. 533).

"However, there is a difference between arguing that ideas are determined by their context and interpreting the historical meaning of texts. Rather than seeking the link between ideas and historical events, historical reconstructions seek to reconstruct the sense (meaning) that someone gave a particular text at some historical point. The most obvious form of historical reconstruction is the effort to understand the original author's meaning" (Emmet 2003, p. 533).

However, Kurz (2016) indicated that not only is it important to remember that the huge changes in the economy over the last few centuries have also changed our view of the economy and society (Kurz 2016, p. 3), but that the history of economic thought is also changing. Each generation writes its own history, new knowledge is always create and each generation is "keen not only on being original but on being perceived as such. But each generation also searches for meaningful progenitors so it can share in their renown and brilliance" (Kurz 2016, p. 2).

We may distinguish between history of economic thought, which is a kind of intellectual history, while other concepts focus more on the history of economic theory. Marcuzzo and Zacchia (2016) distinguished between history of economics and history of economic thought, raising the question of whether they differ. While the first attempts to understand the ideas of past thinkers and how and why those ideas have developed and changed through time (Biddle 2003), the second is much more concerned with very concrete authors, meaning (Faccarello and Kurz 2016) that most research in the history of economic. 
"involved textual exegesis or interpretation; that in a sense the work of most historians of economic thought has been similar to the work of theologians seeking the true interpretations of scriptural writings, or legal scholars and judges seeking the true intent of legislators" (Biddle 2003, p. 2).

Both versions are at the intersection with philosophy and methodology of economics. Empirical studies on journal publications in the area of history of economic thought show clearly the trend that research on individual authors has gone down (Marcuzzo 2008; Marcuzzo and Zacchia 2016). A third topic is economic history. Economic history deals with different empirical facts in a series of social arrangements and physical processes by which human societies have produced the material conditions of human life since the emergence of the human species, mostly devoted to the development of modern economic growth (Headlee 2010). Douglas V. North and R.W. Fogel, two Nobel laureates in economics during the 1990s, worked exactly on those grounds, empirically and methodologically (Greif and Mokyr 2017; Hodgson 2017; Diebolt and Haupert 2018) making a plea for institutional and historical economics and for the need to collect data.

\section{Younger and Older Historical Schools}

The first "battle of methods", which is well-known under its German noun Methodenstreit, contained some very principal arguments which provide a brilliant background understanding for up-to-date debates (Richter 2001). Although the debate between Menger and Schmoller was rather sketchy and polemical, the confrontation between inductive and deductive ways to generate scientific statements makes it a classic piece. The proposed paper tries to embed recent discussion on the issue of realism versus formalism in the scenario of the history of economic thought. The first battle of methods was 120 years ago. This controversy has existed since the first conflict between Gustav Schmoller and Carl Menger, which is still unresolved (Schumpeter 1926; Swedberg 1991). It can be reduced to the principal question of inductive versus deductive working strategies. While Menger, who contemporary with Walras, designed marginal utility theory (Grenznutzentheorie), was a supporter of abstraction and modelling (Menger 1883), Schmoller (1883) believed that empirical research must be carried out to test the theory.

The question of the degree of abstraction (empirical closeness or distance), together with the degree of restriction of scientific theorems, will be addressed with empirical data. This circumstance can further be formulated around the question of the relationship between theory and empiricism in social studies and economics. The aim of theorising is to explain and describe the connections between different variables representing functions in society where classification difficulties arise when the number of variables is high and their sphere of reference is complicated. The clarity of arguments has been expressed repeatedly, namely the questions of empiricism versus theory, presentation of data versus generalisation, and historical reconstruction versus formal theorising. 
The younger and older historical schools in German economics were close to this version of economic history. The German Historical School represented an approach in economics, which had its zenith during the late nineteenth and the first two decades of the twentieth century in Germany. The German Historical School is an essential part of the history of economic thought and it is ultimately identified as a (German) way of old institutionalist thought (Dorfman 1959). Behind the label are different authors and related debates covering nearly 80 years from the 1840 s until the 1920 s, in which academic procedures, methodological standpoints and normative orientations were perpetually changing. The German Historical School did not ultimately unify researchers through a unique view without contradictions, since remarkable conflicts occured between authors commonly identified as members of that school. However, the common bond was that all people associated as members of the historical school were, to a certain degree, concerned with a type of research, which had a focus on historical investigation in relation to economic topics. The profile is most clear as an approach of historicism competing with attempts in economics to formalize economic observation and analysis by universalizing and neglecting the framework of time and space. The credo of the historical school was that researchers should dive into the ocean of economic history with its manifold historical details in order to gather sufficient details that they may be generalized (Shionoya 2001, 2005).

From today's point of view, the German Historical School is of interest because it represents a trend of thought which has many convergences with current ideas of new institutional economics. Also, modern economic sociology, which has newly discovered the idea of social embeddedness of social behaviour and institutions has some intellectual closeness, provides one of the reasons that the German Historical School is perceived to be going through a revival. Another important factor for the relevance of the German Historical School lies in the methodological concerns connected to the schools and their debates. The first two (so-called) "battles of methods" in the social sciences took place on the grounds of that school and involved different proponents. Their arguments are still important pieces in the history of intellectual ideas and methodological concerns.

Literature distinguishes between an "older", "younger" and "youngest" historical school (Herbst 1965). The "older" historical school is represented by writers such as Wilhelm Roscher (1817-1894), Bruno Hildebrand (1812-1878) or Karl G. A. Knies (1821-1898). The "younger" historical school has its most famous representative in the figure of Gustav Schmoller (1838-1917), but authors like Karl Bücher (1847-1930) and Lujo Brentano (1844-1931) are also still well known. For the "youngest" school, commonly Max Weber (1864-1920), Werner Sombart (1863-1941) and Arthur Spiethoff (1873-1957) are counted as the most prominent representatives (Shionoya 2001).

The "older" historical school was not really a school, because the leading authors differed in what they were practicing and they were not very distant from other practices of doing economics. Roscher, Hildebrand or Knies claimed not only the use of statistical data but also conducted methodological reflections on the use of employing statistics. Hildebrand also wrote about the evolutionary character of economic civilization where historical progress was thought of as a ladder starting from the barter economy evolving through monetary economy up to the banking industry. Roscher and Knies both conducted historically informed and inspired macroeconomics, 
which was also guided by ethical ideas. Wealth is not an end-in-itself of economy and society but one of the major questions closely related to issues of life-standards and their measurement. Later, Weber discussed Roscher and Knies and the logical implications of doing historical economics carefully and substantially by emphasising that despite all forms of preliminary thought, Roscher and Knies contributed considerably to the substantial development of historical economics in the nineteenth century (Weber 1988b).

The subsequent "younger" historical school summarized many of those ideas, which were formerly created and consolidated academics substantially. The common denominator was that profound studies in many economic sectors were undertaken and research programs were set up which studied economic sectors, geographic regions or individual branches or occupations in detail in a historical view in order to investigate their related dynamics. Karl Bücher and Gustav Schmoller dealt with the processes of the establishment of modern mass production with limits to growth (Bögenhold 2000). Lujo Brentano and Gustav Schmoller were programmatically engaged in finding a politically contrasting program for the social question of working classes, poverty, housing and living conditions in general. They endeavoured to find a political-academic perspective, which was distant to that of evolving Marxism. What the German Historical School had in mind was a kind of social-reformism within the borders of the constitutional society, which was labelled as "Katheder-Sozialismus" (socialism provided by professors), which was later regarded as a derogatory term by the left-wing workers' movement for not being radical enough.

Schmoller was the informal leader of the "younger" German Historical School, having submitted several books and further studies in which he undertook historically informed studies by using diverse sources. Being an influential professor in Berlin, Schmoller was consulted by the policy administration in Berlin and he converted his networks into power. Schmoller's position was strengthened further once he became president of the Verein für Socialpolitik [Society for Social Policy], which was founded by Schmoller and associates in 1872. The Verein für Socialpolitik was the first academic organization of mainly German speaking economists and still exists today as a major economic organization joining economists of Germany, Austria and Switzerland. The annual conferences were often focused on academic discussion around concrete social problems connected to the rapid industrial-capitalist explosion (housing, handicraft production, working conditions, etc.).

When Schmoller was at the peak of his career, he saw himself confronted with published critiques by the Austrian economist Carl Menger who argued against Schmoller and the German Historical School in general (Backhaus and Hansen 2000; Louzek 2011). Menger, who originated marginal utility theory, which later served to be the consolidation of neoclassic theory in economics, argued against the methodological principles of the German Historical School. Menger's message was that the German Historical School was far from being a theoretical science (Bögenhold 2008). The historical-analytic and in some ways reconstructive-narrative method of the historical school would not be sufficient to meet with the requirements of a theoretical science. The dispute between Menger and Schmoller serves as the first battle of methods in economics. The methodological implications of the controversy are concerned with questions about the status of theory and principal different methods to practical science. At the end, one can conclude that the controversy was about inductive versus deductive 
methods. The history of economic thought and the sociology and philosophy of science both treat this still unresolved battle as classic piece in the history of intellectual ideas.

According to the literature, a "youngest" German Historical School also existed. Max Weber, Werner Sombart and Arthur Spiethoff are regarded as major representatives. Arthur Spiethoff is acknowledged as one of the founding fathers of conducting research on business cycles by employing historical methods. Max Weber and Werner Sombart both conducted historical research, which was connected to the rise of modern capitalism with a strong emphasis on cultural variables for its interpretation. Weber was a professor of economics, whose famous "Economy and Society" (1972) was published posthumously. His work was concerned with reflections on a sociology of science and a sociology of religion. Weber's typology of human motives and behaviour with a categorization of (ideal) types of action, argues against current ideas of a simpleminded homo oeconomicus, which Weber regarded as a non-realistic figure close to a mathematical ideal case.

Weber was an initiator and major proponent of the second battle of methods in which he attacked, again, Schmoller and this research, which was typical for many members of the Verein für Socialpolitik (Swedberg 2000). Textbooks speak about the value judgment debate where Weber said that ethical orientation might be fine but it was also a long way from being a science. He claimed the objectivity of economic statements. Discussions at the annual conferences of the Verein für Socialpolitik were very controversial, such that many members dissolved their membership.

Sombart always assisted Weber in his fights for "objectivity". He succeeded Schmoller's chair after Schmoller's retirement and was well known for his historically, culturally and hermeneutically inspired economics. With his major work "Der moderne Kapitalismus" (Sombart [1902/1927] 1987), attempted "an historical and systematic exposition of Europe's economic life from its beginning to the present day" (Sombart 1982). Sombart's approach was similar to that of Max Weber but with far less emphasis on the role of religious institutions. More than any other thinker, Sombart was responsible for the general introduction and acceptance of the term 'capitalism' as a description of the modern business economy.

The "youngest" German Historical School is of central concern for the current discussion on interdisciplinarity, since convergences between economics, historical scholarship, religious studies and sociology were practised at that time (1880-1930) as a matter of course. Economies were not taken in abstracto but always in concreto, which is not too far from the credo of new institutional thought. Taken as a whole, the German Historical School lost influence over the course of the twentieth century, but it seems that some major ideas are showing signs of recovery in recent times, since many ideas of that school converge with ideas of pluralist economics and arguments for economic institutionalism.

Contemporary discussion is far removed from those debates, which ran a hundred years ago under the slogan of historical schools. Recent economics has become "cleaner" and more theory-driven, but even mainstream authors now write about parallels between old and new institutional economics. Recent scholars, and especially students, should be trained to have some idea of the underlying trends and tendencies of the own academic field. History of economic thought belongs to those tools, which are important to keep the engine of changes visible and to learn to understand directions of change. 


\section{Why Study History of Economic Thought?}

Ten years after the last serious economic crisis, contemporaries still criticize the obvious inability of economics to forecast those economic occurrences appropriately. "What's wrong with modern economics?" was one of the most reported questions. Of course, answers may be diverse and complex, but the fact remains that the best mathematical and econometric modelling techniques did not manage to forecast the development. If economics is a science and more than an ex post reporting branch one must expect that economics is better equipped and also more self-reflexive. In these times, several questions and claims were brought onto the agenda, which must serve as a table of contents for a separate discussion.

Of course, one of the comments was that the academic subject and also recent education in economics has become more invested in history of economic thought, especially as a tool to learn the context of thought and historical knowledge, mistakes and progress. If students receive degrees in economics without having read about, for example, Smith, Keynes, Schumpeter or Hayek, economics is in danger of extinction, and losing economic and social context and the meaning of Begriffsgeschichte or Dogmengeschichte (history of economic terms). We are observing new trends in the mainstream of economics in the sense that the social-scientific nature of economics is increasing (Bögenhold 2000, 2008). There are noticeable trend boundary shifts within and outside of economics (Cedrini and Fiori 2016). However, economists do not systematically acknowledge the appropriate foundation of thought in the social sciences where contemporary authors should always try to draw links to such authors as Marshall, Weber, Pareto and Keynes in order not to unknowingly reinvent ideas which existed already. Not only has the teaching of history of economic thought fallen out of fashion but, consequently, publishing in this field has as well. Marcuzzo and Zacchia (2016) showed that we are experiencing a decline of publications in the area of HET which are concentrated in a small number of journals.

It is interesting enough, that Joseph A. Schumpeter in his "History of Economic Analysis" (1954) already provided the methodological advice, why history of economic theory is (always) needed and why historiography is about more than watching old movies (Bögenhold 2014). Schumpeter argued not only in favour of economic history as rendering a service to economic theory, but also in favour of "a sort of generalized or typified or stylized economic history" (Schumpeter 1954a, p. 20), which includes institutions like private property, free contracting, or government regulation.

According to Schumpeter, there are multiple reasons to study history, pedagogical advantages, new ideas and new insights into the workings of the human mind. First of all, regarding the pedagogical advantages, he argued that for students it is very difficult to approach a field without knowing how it relates to the specific historical time. For a thorough understanding, a historical background is required. One could affirm that methods presently used already embody what has been done in the past, and what is not a part thereof is no longer important. However, present methods and results are meaningful only with reference to their historical background. "Scientific analysis is not simply a logically consistent process that starts with some primitive notions and then adds to the stock in a straight-line fashion. It is not simply progressive discovery of an objective reality" (Schumpeter 1954, p. 4). 
The second reason is that in reading "old" theories, one may discover other interpretations of new ideas; Schumpeter wrote that "our minds are apt to derive new inspirations from the study of the history of science" (Schumpeter 1954, p. 4-5). In his discussion, Schumpeter added an example. The productivity of this experience may be illustrated by the fact that the fundamental ideas that eventually developed into the theory of special relativity occurred first in a book on the history of mechanics (Schumpeter 1954, p. 5).

The third cause is that history can give us insights into the manner in which the human mind works. Particularly in the history of science, various types of logic are used. Scientific performances are self-revelatory by nature; that is, they reveal the mental processes that have taken place in order to arrive at a certain law or theory. "Scientific habits or rules of procedure are not merely to be judged by logical standards that exist independently of them; they contribute something to, and react back upon, the logical standards themselves" (Schumpeter 1954, p. 5).

Finally, the fourth point deals with economics in particular, which is described as a unique historical process. Fundamentally this process does not differ from analogous processes in other fields of knowledge, but,

"much more than in, say, physics is it true in economics that modern problems, methods, and results cannot be fully understood without some knowledge of how economists have come to reason as they do. In addition, much more than in physics have results been lost on the way or remained in abeyance for centuries" (Schumpeter 1954, p. 6).

Given these insightful instructions by Schumpeter as a plea for increased, or at least continuous, attempts to invest in history of economics, one also has to consider Schumpeter's writings as exemplifying what the history of economic writings can highlight. Brilliant ideas are often hidden and neglected for long periods of time. If one wants to analyse a painting hanging on a wall, one must take a few steps back to see the painting as a whole in order to get a sense of the full composition. The same applies to dealing with science and economics specifically. History of economic thought is a neglected academic topic, necessary for contextualizing knowledge, which provides a more sufficient working compass for further study (Kates 2013). If we are really serious that economics is a part of social sciences (Marchionatti and Cedrini 2017) we have to look for links to neighboring fields of economics in the social sciences. Anthropology, sociology, (social-)psychology and, of course, history are to those neighbours (Bögenhold 2018), which always provide fruitful ideas and links to prevent economics from becoming sterile and too insulated.

If modern crises have any benefits, one may be to trigger a careful revision of the systematics of sciences, of tools and common bodies of knowledge. A science without a necessary understanding of the roots of the subject is hard to accept. A graduate in economics who has never read a single line of one of the prominent classic authors of economics is a tragic caricature of a professional person. There are also systematic reasons. New knowledge in economics is made up of, above all, old particles of knowledge combined in new ways (Kurz 2016, p. 4). Going back to Boulding's (1971) rhetorical question of whether Adam Smith was still needed after Samuelson 
was published, economics as well as other social sciences have to learn to interpret their subjects as a permanent over-writing process of academic failures by which we can learn about directions of new knowledge.

Funding Information Open access funding provided by University of Klagenfurt.

Open Access This article is licensed under a Creative Commons Attribution 4.0 International License, which permits use, sharing, adaptation, distribution and reproduction in any medium or format, as long as you give appropriate credit to the original author(s) and the source, provide a link to the Creative Commons licence, and indicate if changes were made. The images or other third party material in this article are included in the article's Creative Commons licence, unless indicated otherwise in a credit line to the material. If material is not included in the article's Creative Commons licence and your intended use is not permitted by statutory regulation or exceeds the permitted use, you will need to obtain permission directly from the copyright holder. To view a copy of this licence, visit http://creativecommons.org/licenses/by/4.0/.

\section{References}

Backhaus, J., \& Hansen, R. (2000). Methodenstreit in der Nationalökonomie. Journal for General Philosophy of Science, 31(2), 307-336.

Backhouse, R. E. (1994). Why and how should we study the history of economic thought? History of Economic Ideas, 2(2), 113-123.

Backhouse, R. E., \& Cherrier, B. (Eds.). (2017). The age of the applied economist: the transformation of economics since the 1970s. History of Political Economy, 49(Supplement), 1-33.

Biddle, J. E. (2003). Research styles in the history of economic thought. In W. J. Samuels, J. E. Biddle, \& J. B. Davis (Eds.), A companion to the history of economic thought (pp. 1-10). Oxford: Blackwell.

Blaug, M. (2001). No history of ideas, please, We're economists. The Journal of Economic Perspectives, 15(1), 145-164.

Boettke, P.F. (2000). Why Read the Classics in Economics?. Library of economics and liberty. [online] available from http://www.econlib.org/library/Features/feature2.html, accessed 13 June 2018, internet.

Bögenhold, D. (2000). Limits to mass production: Entrepreneurship and industrial Organization in View of the historical School of Schmoller and Sombart. International Review of Sociology: Revue Internationale de Sociologie, 10(1), 57-71.

Bögenhold, D. (2008). Economics, sociology, history: Notes on their loss of Unity, their need for re-integration and the current relevance of the controversy between Carl Menger and Gustav Schmoller. Forum for Social Economics, 37(2), 85-101.

Bögenhold, D. (2010). From heterodoxy to orthodoxy and vice versa: Economics and social sciences in the division of academic work. The American Journal of Economics and Sociology, 69(5), 1566-1590.

Bögenhold, D. (2014). Schumpeter as a universal social theorist. The Atlantic Economic Journal, 42(2), 205215.

Bögenhold, D. (2018). Economics between insulation and social-scienciation. Journal of Economic Issues, 52(4), 1127-1144.

Boulding, K. E. (1971). After Samuelson who needs Adam smith? History of Political Economy, 3(2), 225237.

Buckley, P., \& Casson, M. (1993). Economics as an imperialist social science. Human Relations, 46(9), 10351052.

Cedrini, M., \& Fiori, S. (2016). Shifting boundaries, within and outside economics. History of Economic Ideas, 24(3), 11-25.

Cedrini, M., \& Fontana, M. (2018). Just another niche in the wall? How specialization is changing the face of economics. Cambridge Journal of Economics, 42(2), 427-451.

Chafim, F. (2016). Disciplinary division within social sciences. Methodological issues in economic imperialism and economic pluralism. History of Economic Ideas, 24(3), 144-164.

Davis, J. B. (2006). The turn in economics: Neoclassical dominance to mainstream pluralism? Journal of Institutional Economics, 2(1), 1-20.

Davis, J. B. (2016). Economics imperialism versus multidisciplinarity. History of Economic Ideas, 24(3), 7794. 
Davis, J. B., Weintraub, E. R., Mirowski, P., Brewer, A. A., \& Backhouse, R. E. (2002). The future of the history of economics, HOPE annual supplement (Vol. 34). Raleigh: Duke University Press Books.

Diebolt, C., \& Haupert, M. (2018). A cliometric counterfactual: What if there had been neither Fogel nor north? Cliometrica, 12, 407-434.

Dorfman, J. (1959). The economic mind in American civilization (Vol. 5). New York: Viking Press.

Emmet, R. M. (2003). Exegesis, hermeneutics, and interpretation. In W. J. Samuels, J. E. Biddle, \& J. B. Davis (Eds.), A companion to the history of economic thought (pp. 523-537). Oxford: Blackwell.

Faccarello, G., \& Kurz, H. D. (Eds.). (2016). Handbook on the history of economic analysis volume III. Cheltenham: Edward Elgar.

Fogarty, E. A., \& Naples, M. I. (1998). The presence of history: A survey of articles on the history of economic thought and methodology in the economic literature index, 1969-1995. Journal of Economic Issues, 32(1), 224-234.

Fourcade, M., Etienne, O., \& Yann, A. (2015). The superiority of economists. Journal of Economic Perspectives, 29(1), 89-114.

Granovetter, M. S. (2002). A theoretical agenda for economic sociology. In M. F. Guillén, R. Collins, P. England, \& M. Meyer (Eds.), The new economic sociology. Developments in an emerging field (pp. 3560). New York: Russell Sage Foundation.

Greif, A., \& Mokyr, J. (2017). Cognitive rules, institutions and economic growth: Douglass north and beyond. Journal of Institutional Economics, 13(1), 25-52.

Headlee, S. (2010). Economic history. In R. C. Free (Ed.), 21st century economics: A reference handbook (pp. 13-22). London: Sage.

Heilbroner, R. L. (1979). Modern economics as a chapter in the history of economic thought. History of Political Economy, 11(2), 192-198.

Herbst, J. (1965). The German historical School in American Scholarship. Ithaca: Cornell University Press.

Hodgson, G. (2001). How economics forget history. New York: Routledge.

Hodgson, G. (2007). Evolutionary and institutional economics as the new mainstream? Evolutionary and Institutional Economics Review, 4(1), 7-25.

Hodgson, G. (2017). Introduction to the Douglass C. North memorial issue. Journal of Institutional Economics, 13(1), 1-23.

Hodgson, G. M., Mäki, U., \& McCloskey, D. (1992). Plea for a pluralistic and rigorous economics. American Economic Review, 82(2), 25.

Kates, S. (2013). Defending the history of economic thought. Cheltenham: Edward Elgar.

Keynes, J. M. (1936). The general theory of employment, interest and money. London: Macmillan.

Klaess, M. (2003). Historiography. In W. J. Samuels, J. E. Biddle, \& J. B. Davis (Eds.), A companion to the history of economic thought (pp. 491-505). Oxford: Blackwell.

Kurz, H. D. (2016). Economic thought. A brief history. New York: Columbia University Press.

Laidler, D. (2001). The Role of the History of Economic Thought in Modern Macroeconomics. Department of Economics Research Reports, 2001-6. London.

Lazear, E. P. (2000). Economic Imperialism. The Quarterly Journal of Economics, 115(1), 99-146.

Louzek, M. (2011). The battle of methods in economics. The classical Methodenstreit -Menger vs. Schmoller. The American Journal of Economics and Sociology, 70(2), 439-463.

Marchionatti, R., \& Cedrini, M. (2017). Economics as social science: economics imperialism and the challenge of interdisciplinary. London: Routledge.

Marcuzzo, M. C. (2008). Is history of economic thought a serious subject? The Erasmus Journal of Philosophy and Economics, 1(1), 107-123.

Marcuzzo, M. C., \& Zacchia, G. (2016). Is history of economics what historians of economic thought do? History of Economic Ideas, 24(3), 29-46.

Menger, C. (1883). Untersuchungen über die Methode der sozialwissenschaften und der Politischen Ökonomie insbesondere. Leipzig: Duncker and Humblot.

Morgan, M. (2012). The world in the model. How economists work and think. Cambridge: Cambridge Univ Press.

Richter, R. (2001). 'Bridging old and new institutional economics: Gustav Schmoller, the leader of the younger German historical school, seen with neoinstitutionalists' eyes. Research Paper, University of Saarland.

Romer, P. M. (2015). Mathiness in the theory of economic growth. American Economic Review, 105(5), 8993.

Roncaglia, A. (2014). Should the history of economic thought be included in undergraduate curricula? Economic Thought, 3(1), 1-9. 
Samuels, W. (1997). The work of historians of economic thought. Research in the History of Economic Thought and Methodology, 15, 188-198.

Schabas, M. (1992). Breaking away: History of economics as history of science. History of Political Economy, 24(1), 187-203.

Schmoller, G. (1883). Zur Methodologie der Staats-und Sozialwissenschaften, Jahrbuch für Gesetzgebung, Verwaltung und Volkswirtschaft im deutschen Reich (pp. 239-258), Leipzig: Duncker \& Humblot.

Schumpeter, J. A. (1926). Gustav von Schmoller und die Probleme von heute. Jahrbuch für Gesetzgebung, Verwaltung und Volkswirtschaft im deutschen Reich (pp 337-388), Leipzig: Duncker and Humblot.

Schumpeter, J. A. (1954). History of economic analysis. Oxford: Oxford University Press.

Shionoya, Y. (Ed.). (2001). The German historical school: The historical and ethical approach to economics. London: Routledge.

Shionoya, Y. (2005). The soul of the German historical school: Methodological essays on Schmoller, Weber and Schumpeter. New York: Springer.

Sombart, W. (1982). Wirtschaft. In A. Vierkandt (Ed.), Handwörterbuch der Soziologie (pp. 209-216). Stuttgart: Enke.

Sombart, W. (1987). Der moderne Kapitalismus. Munich: DTV.

Swedberg, R. (1991). The battle of methods: Toward a paradigm shift? In A. Etzioni, \& P. R. Lawrence (Eds.) Socio-economics. Toward a new synthesis (pp. 13-34). New York and London: M. E. Sharpe.

Swedberg, R. (2000). Max Weber and the idea of economic sociology. Princeton: Princeton University Press.

Vaughn, K. L. (1993). Why teach the history of economics? Journal of the History of Economic Thought, 15(2), 174-183.

Viner, J. (1917). Some problems of logical method in political economy. Journal of Political Economy, 25(3), 236-260.

Weber, M. (1972). Wirtschaft und Gesellschaft. Tübingen: J.C.B. Mohr.

Weber, M. (1988a). Wissenschaft als Beruf. In M. Weber (Ed.), Gesammelte Aufsätze zur Wissenschaftslehre (pp. 524-555). Tübingen: J.C.B. Mohr.

Weber, M. (1988b). Gesammelte Aufsätze zur Wissenschaftslehre. Tübingen: J.C.B. Mohr.

Weintraub, E. R. (2002). How economics became a mathematical science. Durham: Duke University Press.

Winch, D. N. (1962). What Price the history of economic thought. Scottish Journal of Political Economy, 9(3), 193-204.

Wunder, T. A. (2010). Economic methodology. In R. C. Free (Ed.), 21st century economics: A reference handbook (pp. 23-32). London: Sage.

Publisher's Note Springer Nature remains neutral with regard to jurisdictional claims in published maps and institutional affiliations. 